\title{
STATUS KEBERLANJUTAN SISTEM PENGELOLAAN AIR LIMBAH DOMESTIK KOMUNAL BERBASIS MASYARAKAT DI KOTA PROBOLINGGO
}

\author{
Yusdi Vari Afandi (1), Henna Rya Sunoko (1,2), Kismartini $(1,3)$ \\ (10 Program Magister IImu Lingkungan Undip, bangyusdi@gmail.com \\ (2) Program Doktor IImu Lingkungan Undip, hennarsunoko@gmail.com \\ (3)c Program Magister IImu Administrasi Publik, kis martini@yahoo.co.id
}

\begin{abstract}
ABSTRAK
Konsep pengelolaan berbasis masyarakat dalam pembangunan sarana pengolahan air limbah domestik komunal disinyalir hanya mengedepankan pembangunan fisik saja tanpa memperhatikan kesiapan sumber daya manusia di tingkat lokal sehingga sering kali pembangunan sarana tersebut gagal dan tidak berkelanjutan. Penelitian ini bertujuan untuk mengetahui status keberlanjutan sistem pengelolaan air limbah (IPAL) komunal berbasis masyarakat di Kota Probolinggo serta merumuskan strategi yang diperlukan untuk mempertahankan keberlanjutan sistem. Penelitian dilakukan di Kelurahan Pilang dan Mayangan dengan jumlah responden total 107 orang yang mewakili keluarga pemanfaat sarana IPAL komunal. Status keberlanjutan sistem pengelolaan air limbah komunal di Kota Probolinggo masuk kategori sedang dengan skor 2,30. Kondisi tersebut didukung oleh pemilihan teknologi yang tepat baik dari sisi kehandalam maupun kemudahan pengoperasian dan pemeliharaannya sehingga menghasilkan penurunan beban pencemaran yang tinggi. Pengelolaan air limbah domestik komunal dilakukan oleh kelembagaan di tingkat lokal dalam berbentuk Kelompok Swadaya Masyarakat (KSM), namun dalam pelaksanaannya belum sepenuhnya optimal. Telah memiliki mekanisme pembiayaan untuk operasional dan pemeliharaan, keterlibatan masyarakat dalam pembangunan dilakukan melalui kontribusi dalam bentuk incash dan inkind, sedangkan keterlibatan masyarakat dalam tahap operasional yang nampak adalah kesediaan membayar iuran rutin sebesar Rp. 1000/bulan untuk Kelurahan Pilang dan Rp. 3000/bulan untuk Kelurahan Mayangan. Strategi yang diperlukan dalam upaya meningkatkan keberlanjutan sistem pengelolaan air limbah domestik komunal di Kota Probolinggo adalah pengembangan kapasitas masyarakat dan kelembagaan pengelola air limbah, pengembangan alternatif pembiayaan pengelolaan air limbah berbasis kemitraan, dan peningkatan koordinasi serta pembagian peran pada POKJA sanitasi dalam mendukung pengelolaan air limbah di tingkat lokal.
\end{abstract}

Kata Kunci : Air Limbah Domestik, Keberlanjutan,Pengelolaan Berbasis Masyarakat, Sistem komunal

\begin{abstract}
The community-based management conceptofcummunal domestic wastewater treatment facilities development is considered just to emphasize physical construction only without taking a note the readiness of human resources at the local level, consequently, the development of that facilities often failed and unsustainable. This research aimed to know the sustainability status of the community-based ofcummunal domestic wastewater management systems in Probolinggo City formulate the strategiy required to maintain that sustainability system. The research conducted in Pilangand Mayangan districts with amount of repondents 107 people as representative ofthose facilitiy custamers. Sustainability status of cummunal domestic wastewater management systems in Pilang and Mayangan district still in high score, 2.35 score (Pilang ) and 2.37score (Mayangan ). This condition supported by appropriate technology selection in many side, the reliabilityand the simplicity of operation and
\end{abstract}


maintenance system, so it make the high pollution load can be decreased. Wastewater management, in those two districts, they have had management organization in local level, organized as self-supporting organization or Kelompok Swadaya Masyarakat (KSM). However, in the implementation is not optimimal yet. They also have had financial mechanism related to operational and maintenance cost. Moreover community involvement in Pilangand Mayangan districts lead by contribution inkindand incash. Whereas, community involvement in the operational phase,showed by the willingness to pay the retribution 1000 per month(Pilang) and 3000 per month (Mayangan). Strategies required maintaining the sustainability system are region expansion, optimizesanitation work group (POKJA) and planning of big scale centralized wastewater management system development to cope with the area limitation.

Keyword: Domestic Wastewater, Sustainability, Cummunity-Based Management, Communal System

\section{Pendahuluan}

Konsep pengelolaan berbasis masyarakat (Community Based Management) saat ini dianggap sebagai konsep yang sesuai dalam menjalankan program pembangunan sarana sanitasi khususnya sarana pengolahan air limbah domestik di wilayah perkotaan (urban) dan perdesaan (peri urban) di negara-negara berkembang seperti Indonesia. Konsep ini menitikberatkan pada keterlibatan masyarakat dalam setiap tahap pembangunan mulai dari tahap perencanaan, pembangunan hingga operasional dan pemeliharaan sehingga diharapkan timbul rasa memiliki dari masyarakat terhadap fasilitas yang ada.

Berbagai penyesuaian dilakukan agar pelaksanaan pengelolaan berbasis masyarakat ini dapat berjalan secara optimal, dan tujuan utama yaitu peningkatan taraf hidup masyarakat dan penurunan beban pencemar juga tercapai. Penyesuaian dilakukan dengan berbagai pertimbangan mulai dari pemilihan teknologi yang tepat dan dapat diterima oleh masyarakat, pola kelembagaan hingga pola partisipasi masyarakat sesuai agar pengelolaan sistem dapat berjalan. Namun, tentunya hal tersebut membutuhkan waktu yang tidak pendek dalam mempersiapkan sumber daya manusia yang ada. Di sisi lain, pemerintah dituntut dalam pencapaian target MDG's pada tahun 2015 sebesar 62,41\% rumah tangga di Indonesia harus mendapatkan akses layanan sanitasi yang layak dan berkelanjutan. Menurut Bappenas (2012), pencapaian target MDG's pada tahun 2011 khususnya propos rumah tangga di perkotaan dan perdesaan dengan akses sanitasi yang layak dan berkelanjutan masih mencapai 55,60\% (perkotaan sebesar 72,54\% dan perdesaan sebesar 38,97\%). Hal ini menunjukkan perlu upaya percepatan pembangunan di bidang sarana sanitasi.

Tantangan lain yang dihadapi adalah jumlah penduduk di Indonesia yang setiap tahun terus meningkat. Berdasarkan hasil proyeksi penduduk selama 25 tahun ke depan, jumlah penduduk Indonesia yang sebelumnya 219,8 juta pada tahu 2005 meningkat menjadi 270,5 juta pada tahun 2025 dengan sebaran penduduk yang tidak merata (Bappenas, 2008). Hal ini akan berdampak terhadap semakin terbatasnya ketersediaan lahan bagi permukiman dan potensi peningkatan beban pencemaran, baik pada air permukaan maupun air bawah tanah. Fatnasari dan Hermana (2010) menyatakan bahwa penurunan kualitas air sungai 60\% disebabkan buangan air limbah permukiman, sedangkan pencemaran terhadap air bawah tanah disebabkan karena potensi kebocoran dari septictank yang cukup tinggi. Kondisi ini diperkuat oleh penelitian Sudjonoet al. (2010) di Jawa Timur yang menyatakan bahwa septictank yang ada di masyarakat pada umumnya jarang dikuras setelah lebih dari 15 tahun beroperasi.

Melihat fenomena tersebut, program pembangunan sarana sanitasi khususnya sarana pengolahan air 
limbah dengan konsep pengelolaan berbasis masyarakat yang telah dilaksanakan selama ini disinyalir lebih mengedepankan penyediaan sarana fisik saja tanpa memperhatikan kesiapan sumber daya manusia di tingkat lokal yang akan menjadi pengelola sarana tersebut, sehingga tidak ada jaminan terhadap keberlanjutan sistem pengelolaannya.

Berbagai penelitian telah dilakukan terhadap sistem pengelolaan air limbah domestik khususnya bagi negara berkembang. Prihandrijanti dan Firdayati (2011) dalam penelitiannya menyatakan bahwa sistem pengelolaan terpusat/komunal lebih sesuai diterapkan di kota-kota di Indonesia karena di samping lebih menguntungkan dari sisi pengoperasian dan perawatan, juga menjadi solusi bagi daerah dengan tingkat kepadatan yang tinggi. Selain itu, faktor sumber daya manusia yang meliputi kemauan dan kemampuan masyarakat, faktor ekonomi serta komitmen kebijakan politik suatu daerah juga dapat mempengaruhi efektifitas pengelolaan air limbah sistem terpusat/ komunal (Massoudet al.2010).

Penelitian ini bertujuan untuk mengkaji status keberlanjutan sistem pengelolaan air limbah permukiman komunal yang menerapkan konsep Community Based Management di Kota Pobolinggo, Provinsi Jawa Timur, serta merumuskan strategi dalam meningkatkan atau mempertahankan keberlanjutan sistem tersebut.

\section{Metode Penelitian}

Penelitian ini merupakan penelitian deskriptif kualitatif dengan pendekatan studi kasus. Lokasi penelitian dilakukan di Kelurahan Mayangan, Kecamatan Mayangan dan Kelurahan Pilang, Kecamatan Kademangan. Penentuan lokasi didasarkan pada wilayah yang telah menerima program pembangunan sarana sistem pengelolaan air limbah komunal dengan konsep pengelolaan berbasis masyarakat.
Variabel yang digunakan dalam penelitian ini adalah aspek teknis, pembiayaan, kelembagaan, peranserta masyarakat dan kualitas lingkungan. Data yang dihasilkan bersifat kualitatif dan kuantitatif yang diperoleh dari hasil observasi, wawancara, penelaahan dokumen dan uji laboratorium terhadap kualitas effluent IPAL. Data kuantitatif diperoleh selain melalui uji laboratorium, juga diperoleh dari hasil wawancara terstruktur dengan memberi skor pada interval $1 \mathrm{~s} / \mathrm{d} 3$ pada setiap jawaban responden yang memiliki gradasi makna buruk, sedang dan baik, sedangkan data kualitatif diperoleh dari hasil observasi dan wawancara mendalam terhadap key person

Teknik pengambilan sampel untuk responden ditentukan dengan metode Purposive Sampling di mana responden yang dipilih adalah setiap anggota keluarga pemanfaat/ pengguna IPAL komunal sehingga jumlah responden di Kelurahan Mayangan berjumlah 32 orang, sedangkan di Kelurahan Pilang berjumlah 75 orang. Teknik pengambilan sampel untuk air limbah pada outlet IPAL dilakukan dengan metode Grab Sampling dengan pengulangan sebanyak dua kali yaitu bulan Mei 2013 dan Juni 2013.

Analisis status keberlanjutan dilakukan melalui perhitungan hasil skoring berdasarkan indikator dari masing-masing variabel penelitian sehingga diperoleh status keberlanjutan dengan skala $(1,00 \quad-1,66)$ rendah, $(1,67-2,33)$ sedang dan $(2,34-3,00)$ tinggi. Perumusan strategi keberlanjutan dilakukan melalui Analisis SWOT yang menginteraksikan faktorfaktor internal dan eksternal pada masing-masing lokasi penelitian.

\section{Hasil Dan Pembahasan}

\subsection{Gambaran Umum}

Kota Probolinggo merupakan salah satu wilayah di Provinsi Jawa Timur yang memiliki luas wilayah sebesar 56,667 $\mathrm{km}^{2}$ dengan jumlah penduduk 218.061 jiwa. Kota Probolinggo terbagi menjadi lima 
wilayah kecamatan, yaitu Kecamatan Mayangan, Kademangan, Kanigaran, Wonoasih dan Kedupok. Lokasi penelitian difokuskan pada Kecamatan Mayangan dan Kademangan, tepatnya di Kelurahan Mayangan dan Pilang. Kelurahan Pilang memilki luas wilayah lebih luas dibandingkan Kelurahan Mayangan yaitu 3,068 $\mathrm{km}^{2}$ atau 5,41 \% dari luas Kota Probolinggo, sedangkan Kelurahan Mayangan hanya memiliki luas $1,276 \mathrm{~km}^{2}$ atau 2,25\% dari luas Kota Probolinggo. Namun demikian, berdasarkan hasil registrasi kependudukan tahun 2011 kepadatan penduduk Mayangan lebih tinggi yaitu sebesar 8.059 jiwa/ $\mathrm{km}^{2}$, sedangkan kepadatan penduduk Kelurahan Pilang 1.869 jiwa/ km² (BPS, 2012), sehingga ini menunjukkan bahwa sebaran penduduk di kedua kelurahan tersebut tidak merata. Selain itu, Kelurahan Mayangan telah ditetapkan sebagai wilayah dengan kondisi sanitasi beresiko tinggi sedangkan Kelurahan Pilang masuk dalam kategori sedang (Bappeda, 2010)

\subsection{Aspek Teknis}

Berdasarkan hasil observasi diketahui bahwa sistem pengelolaan air limbah di Kelurahan Pilang dan Mayangan dibangun secara komunal dengan menghubungkan saluran buangan air limbah baik grey water (mandi, cuci dan kakus) maupun black water (jamban) di masing-masing rumah melalui saluran utama menuju Instalasi Pengolahan Air Limbah (IPAL) komunal. Cakupan jaringan saluran air limbah di Kelurahan Pilang meliputi 75 kepala keluarga (KK) di wilayah RT04-05/RW03, sedangkan di Kelurahan Mayangan meliputi $32 \mathrm{KK}$ di wilayah RT 07/ RW 03.

Teknologi pengolahan air limbah yang digunakan pada IPAL di kedua kelurahan adalah Anaerobic Baffle Reactor (ABR). ABR merupakan modifikasi teknologi septictank di mana didalamnya terdapat dinding penyekat (baffle) yang berfungsi untuk memaksa air limbah mengalir melewati alurnya secara naik turun (Kurniawan, 2012).
Teknologi ini dipilih karena dianggap sebagai teknologi yang sederhana namun memiliki efisiensi tinggi. Untuk itu, teknologi ini sesuai untuk digunakan pada sistem pengelolaan air limbah berbasis masyarakat. Hal ini sebagaimana yang dinyatakan oleh Balkemaet al.(2002), bahwa desain teknologi pengolahan air limbah yang lebih diterima oleh masyarakat akan merangsang peningkatan kesadaran, peranserta masyarakat dan tanggung jawab masyarakat.

Penentuan dimensi IPAL didasarkan kepada jumlah calon pengguna sarana IPAL (dalam jiwa) sehingga diketahui jumlah air limbah yang akan diolah. Menurut Hindarko (2003) sekitar 60 - 80\% dari kebutuhan air bersih setiap orang dapat diperhitungkan sebagai debit air limbah yang akan terlayani oleh sistem air limbah. Sedangkan kebutuhan air bersih untuk kota sedang (100.000500.000 jiwa) adalah 130 liter/ orang/hari. Kapasitas desain IPAL komunal terbangun di Kelurahan Pilang diperuntukkan untuk 305 jiwa, sedangkan Kelurahan Mayangan diperuntukkan untuk 356 jiwa. Sehingga diperoleh kapasitas desain air limbah untuk Kelurahan Pilang sebesar 31,72m3/ hari dan Kelurahan Mayangan sebesar $37,02 \mathrm{~m} 3 / \mathrm{hr}$. Sedangkan berdasarkan survey, jumlah pemanfaat IPAL komunal di Kelurahan Pilang berjumlah $75 \mathrm{KK}$ atau 277 jiwa, sedangkan Kelurahan Mayangan hanya berjumlah $32 \mathrm{KK}$ atau 138 jiwa. Sehingga air limbah yang terolah untuk Kelurahan Pilang sebesar 31,20m3/ hr atau 98,36\% dari kapasitas yang direncanakan dan 13,31m3/hr atau 35,95\% dari kapasitas yang direncanakan. Hal ini menunjukkan bahwa cakupan penggunaan jaringan air limbah komunal masih di bawah kapasitas desain yang direncanakan terutama di Kelurahan Mayangan, sehingga khusus di Kelurahan Mayangan pengembangan cakupan sambungan rumah masih dapat dilakukan. 


\subsection{Aspek Pembiayaan}

Balkema etal (2002) menyatakan bahwa indikator keberlanjutan yang digunakan pada sistem pengolahan air limbah pada aspek ekonomi meliputi biaya investasi, operasional dan pemeliharaan termasuk di dalamnya keterjangkauan pembiayaan dan biaya tenaga kerja. Dalam konteks pembiayaan pembangunan sarana pengolahan air limbah, kontribusi masyarakat diharapkan tetap ada baik dalam bentuk incash (uang) dan inkind (material). Menurut Kustiah (2005), pola pembiayaan sarana pengolahan air limbah yang diserahkan pada masyarakat biasanya diwujudkan dalam bentuk lahan, sambungan rumah, fasilitas di dalam rumah (jamban dan kamar mandi), dan tenaga kerja.

Berdasarkan hasil penelitian diketahui bahwa biaya investasi proyek pembangunan sarana IPAL di Kelurahan Pilang dan Mayangan masih didominasi oleh pemerintah melalui danaAPBN yang diwujudkan dalam bentuk program Sanitasi Lingkungan Berbasis Masyarakat (SLBM) dan Sanitasi Perkotaan Berbasis Masyarakat (SPBM). Kontribusi masyarakat dalam bentuk incash (uang) hampir dipastikan tidak ada. Sebagian masyarakat berontribusi dalam bentuk tenaga atau material berupa konsumsi dan peralatan pertukangan di mana total nilai kontribusi masyarakat Kelurahan Pilang sebesar Rp. 22.152.000,- (7,7 \%), sedangkan kontribusi masya-rakat Kelurahan Mayangan sebesar Rp. 4.029.000,- (1,15\%)).

Biaya operasional dan pemeliharaan dalam pengelolaan air lmbah di Kelurahan Pilang dan Mayangan digunakan untuk biaya petugas inspeksi jaringan perpipaan, pengurasan lumpur IPAL dan perbaikan kerusakan instalasi. Mekanisme pendanaan dilakukan melalui iuran bulanan yang besarannya ditetapkan melalui musyawarah. Besaran iuran di Kelurahan Pilang adalah Rp. 1000,- sedangkan di Kelurahan Mayangan sebesar Rp. 3000,-. Tabel 1 menunjukkan kemampuan dan kemauan masyarakat membayar iuran lebih tinggi dari iuran yang ditetapkan.

Berdasarkan Tabel 1 nampak bahwa masyarakat merasa mampu dan bersedia membayar iuran tersebut secara rutin bahkan 58,67\% masyarakat Pilang dan $75 \%$ masyarakat Kelurahan Mayangan bersedia membayar lebih tinggi dari iuran yang telah ditetapkan.

Kemauan masyarakat untuk membayar iuran lebih tinggi dari iuran yang telah ditetapkan menunjukkan bahwa harapan masyarakat yang tinggi terhadap keberlanjutan layanan sistem yang ada, terutama masyarakat Kelurahan Mayangan yang sebelum adanya sarana pengolahan air limbah tersebut, untuk buang air besar saja mereka harus pergi ke laut.

Tabel 1. Kemampuan dan Kemauan Masyarakat dalam Membayar

\begin{tabular}{lcrcr}
\hline \multirow{2}{*}{$\begin{array}{c}\text { Besaran } \\
\text { Iuran }\end{array}$} & \multicolumn{2}{c}{$\begin{array}{c}\text { Eelurahan } \\
\text { Pilang }\end{array}$} & \multicolumn{2}{c}{$\begin{array}{c}\text { Kelurahan } \\
\text { Mayangan }\end{array}$} \\
\cline { 2 - 5 } & $\mathrm{N}$ & \multicolumn{1}{c}{$\%$} & $\mathrm{~N}$ & \multicolumn{1}{c}{$\%$} \\
\hline Rp. 2.000 & 20 & 26,67 & 0 & 0,00 \\
Rp. 3.000 & 6 & 8,00 & 0 & 0,00 \\
Rp. 5.000 & 14 & 18,67 & 23 & 71,87 \\
Rp. 10.000 & 4 & 5,33 & 1 & 3,13 \\
Tidak & 31 & 41,33 & 8 & 25,00 \\
bersedia & \multicolumn{1}{c}{10} \\
\hline Jumlah & 75 & $100,00 \%$ & 32 & 100,00 \\
\hline
\end{tabular}

Sumber :Data Primer, 2013

\subsection{Aspek Kel embagaan}

Kelembagaan di tingkat lokal dengan didukung oleh komitmen dan kebijakan pemerintah merupakan faktor yang mempengaruhi keberlanjutan sistem mengelola sistem pengelolaan air limbah (Parkinson dan Teyler, 2003). Pengelolaan air limbah komunal di Kelurahan Pilang dan Mayangan diserahkan pada masyarakat dengan membentuk kelembagaan lokal berupa Kelompok Swadaya Masyarakat (KSM) Barokah untuk Kelurahan Pilang dan KSM Putra Samudra untuk Kelurahan Mayangan.

Pola kelembagaan di Kelurahan Pilang diwujudkan dalam pembentukan KSM yang beranggotakan pengurus 
RT/RW dan tokoh masyarakat yang tidak satupun menjadi pemanfaat sarana IPAL, mekanisme pengambilan keputusan dilakukan melalui musyawarah yang melibatkan pengurus KSM dan tokoh masyarakat yang mewakili masyarakat, selanjutnya hasil keputusan disosialisasikan kepada masyarakat pemanfaat IPAL. Berdasarkan hasil wawancara dengan pengurus KSM, mekanisme ini dilakukan karena jumlah pemanfaat yang banyak sehingga tidak efektif jika semua masyarakat dilibatkan. Pola kelembagaan di Kelurahan Mayangan diwujudkan dalam pembentukan KSM dan Kelompok Pemelihara dan Pemanfaat (KPP). KSM beranggotakan pengurus RT/ RW, tokoh masyarakat dan perwakilan calon pemanfaat yang bertugas mulai tahap perencanaan hingga tahap pembangunan sarana IPAL, sedangkan KPP beranggotakan masyarakat pemanfaat yang bertugas dalam pengelolaan IPAL pasca tahap pembangunan. Pengambilan keputusan dilakukan melalui musyawarah seluruh masyarakat pemanfaat. Namun demikian, secara umum fungsi kelembagaan di kedua kelurahan tersebut belum berjalan secara optimal. Kegiatan yang terlihat hanya pengumpulan iuran untuk dana operasional, sedangkan kegiatan pemeliharaan fisik sebagaimana yang direncanakan dalam rencana kerja masyarakat (RKM) seperti inspeksi saluran belum pernah dilakukan.

Dukungan pemerintah terhadap program pembangunan sanitasi di Kota Probolinggo diwujudkan dengan peyusunan dokumen Strategi Sanitasi Kota (SSK) dan pembentukan Kelompok Kerja (POKJA) Sanitasi yang berfungsi untuk mengintegrasikan peran dan tugas dari masing-masing satuan kerja dalam pembangunan sanitas dimana anggotanya meliputi Bappeda, Badan Lingkungan Hidup, Dinas PU Cipta Karya, Dinas Kesehatan dan Kantor Pemberdayaan Masyarakat. Namun demikian, dalam pelaksanaanya fokus kegiatannya masih sebatas pada kegiatan perencanaan dan pembangun- an fisik sarana, sedangkan kegiatan yang bersifat monitoring dan pembinaan yang bertujuan untuk meningkatkan kapasitas kelembagaan dan sumber daya manusia masih jarang dilakukan, terutama pada pasca tahap pembangunan. Hal ini dapat dibuktikan dari hasil wawancara dengan responden yang menunjukkan bahwa 98,67\% (Kelurahan Pilang) dan 87,5\% (Kelurahan Mayangan) masyarakat mengaku pelum pernah mendapatkan pelatihan maupun penyuluhan tentang pengelolaan air limbah.

Upaya peningkatan kapasitas ini menjadi penting untuk dilakukan, karena menurut Massoudet al (2010) faktor sumber daya manusia baik berupa kemauan maupun kemampuan masyarakat akan mempengaruhi efektifitas penggunaan sistem pengolahan air limbah komunal. Sebagai gambaran terhadap tingkat pengetahuan masyarakat terhadap sistem yang ada, menunjukkan bahwa masyarakat di Kelurahan Pilang (65,33 \%) dan Kelurahan Mayangan (78,13\%) mengaku tidak tahu tentang fungsi dan tujuan dibangunnya sistem pengolahan air limbah komunal yang ada. Hal ini menunjukkan bahwa kegiatan pelatihan atau penyuluhan perlu dilakukan lebih intensif untuk memberikan pemahaman pada masyarakat tentang sistem yang ada sehingga keberlanjutan sistem dapat meningkat

\subsection{Aspek Peranserta Masyarakat}

Peranserta masyarakat dalam pengelolaan air limbah komunal diharapkan muncul mulai tahap perencanaan hingga tahap operasional dan perencanaan. Dalam tahap perencanaan, masyarakat diharapkan terlibat dalam setiap pengambilan keputusan diantaraya dalam pemilihan teknologi dan pemilihan lokasi IPAL. Tabel 3 memberikan gambaran tingkat keterlibatan masyarakat di Kelurahan Pilang dan Mayangan pada tahap perencanaan : 
Tabel 2. Keterlibatan Mayarakat pada Tahap Perencanaan

\begin{tabular}{lcccc}
\hline \multirow{2}{*}{ Bentuk Keterlibatan } & \multicolumn{2}{c}{ Pilang } & \multicolumn{2}{c}{ Mayangan } \\
\cline { 2 - 5 } & $\mathrm{N}$ & $\%$ & $\mathrm{~N}$ & $\%$ \\
\hline $\begin{array}{l}\text { Tingkat kehadiran di } \\
\text { setiap pertemuan }\end{array}$ & 65 & 86,67 & 16 & 50,00 \\
$\begin{array}{l}\text { Kontribusi usulan } \\
\text { dalam setiap } \\
\text { pertemuan }\end{array}$ & 5 & 6,67 & 6 & 18,75 \\
$\begin{array}{l}\text { Keterlibatan dalam } \\
\text { pemilihan teknologi }\end{array}$ & 0 & 0,00 & 0 & 0,00 \\
$\begin{array}{l}\text { Keterlibatan dalam } \\
\text { penentuan lokasi } \\
\text { IPAL }\end{array}$ & 6 & 8,00 & 5 & 15,63 \\
\hline \multicolumn{1}{c}{ Sumber :Data Primer, 2013 } & & &
\end{tabular}

Berdasarkan tabel di atas, terlihat bahwa keterlibatan masyarakat pada tahap perencanaan cukup rendah. Hal ini disebabkan oleh dominasi pemerintah dan fasilitator masih tinggi, terutama dalam pemilihan teknologi yang digunakan dalam pembangunan tersebut. Menurut Masduki et al. (2008), peranserta yang rendah biasanya disebabkan masyarakat kurang membutuhkan keberadaan sarana tersebut atau sarana yang ada kurang sesuai dengan yang mereka harapkan. Namun demikian, hasil survey menunjukkan bahwa $84 \%$ masyarakat Kelurahan Pilang dan 68,75 $\%$ masyarakat Kelurahan Mayangan mengaku menerima pembangunan sarana IPAL tersebut atas dasar kebutuhan akan fasilitas sanitasi dan lebih dari $95 \%$ masyarakat di kedua kelurahan tersebut setuju terhadap proyek pembangunan sarana IPAL tersebut.

Peranserta masyarakat pada tahap pembangunan terlihat dari bentuk kontribusi yang diberikan. Berdasarkan survey, bentuk keterlibatan masyarakat yang dominan dalam tahap pembanguan adalah tenaga yaitu sebesar 76\% (Kelurahan Pilang) dan 56,25\% (Kelurahan Mayangan). Kontribusi dalam bentuk material umumnya berupa konsumsi bagi tenaga kerja yang diterapkan secara bergiliran setiap kepala keluarga. Untuk Kelurahan Pilang, selain berupa konsumsi kontribusi material juga diwujudkan berupa peralatan pertukangan, karena sebagian besar tenaga kerja berasal dari masyarakat setempat.

Pada tahap operasional dan pemeliharaan, peranserta masyarakat diwujudkan dalam keikutsertaannya dalam pemeliharaan sistem yang ada baik dalam bentuk kerja bakti pembersihan saluran maupun secara mandiri. Berdasarkan hasil wawancara, belum pernah dilakukan kerja bakti yang melibatkan masyarakat dalam pembersihan saluran sedangkan kegiatan yang bersifat mandiri dan inisiatif masyarakat, 82,67 \% masyarakat Kelurahan Pilang dan 15,63 \% menyatakan tidak pernah terlibat. Alasan yang dikemukakan adalah karena mereka telah membayar biaya pemeliharaan setiap bulannya dan kegiatan pemeliharaan merupakan tanggung jawab lembaga pengelola IPAL. Hal ini biasanya disebabkan karena kurangnya sosialisasi terhadap masyarakat tentang fungsi dan tanggung jawab lembaga pengelola dan masyarakat sebagai pengguna.

\subsection{Aspek Kualitas Lingkungan}

Tujuan pembangunan sarana IPAL tentunya tidak hanya untuk meningkatkan derajat kesehatan dan taraf hidup masyarakat, melainkan dari aspek ekologis juga diharapkan dapat memberikan kontribusi terhadap penurunan beban pencemaran baik ke air permukaan ataupun air bawah tanah. Indikator keberlanjutan untuk aspek kualitas lingkungan ini adalah kehandalan teknologi yang digunakan dalam menurunkan beban pencemar yang diolah melalui pengukuran konsentrasi parameter air limbah domestik pada outlet IPAL. 
Tabel 3. Kinerja Instalasi Pengolahan Air Limbah

\begin{tabular}{|c|c|c|c|c|}
\hline \multirow[b]{2}{*}{ Parameter } & \multicolumn{4}{|c|}{ Kualitas ParameterAir Limbah } \\
\hline & $\mathrm{pH}$ & $\begin{array}{c}\mathrm{BOD} \\
(\mathrm{mg} / \mathrm{l})\end{array}$ & $\begin{array}{c}\text { TSS } \\
(\mathrm{mg} / \mathrm{l})\end{array}$ & $\begin{array}{c}\text { Minyak } \\
\& \text { Lemak }(\mathrm{mg} / \mathrm{l})\end{array}$ \\
\hline Influent & - & 353,43 & 119,25 & 63 \\
\hline Effluent: & & & & \\
\hline a. Pilang & 7,52 & 11,01 & 12,20 & 1,08 \\
\hline $\begin{array}{l}\text { b. Mayangan } \\
\text { \% tase: }\end{array}$ & 7,33 & 9,36 & 10,80 & 1,05 \\
\hline a. Pilang & - & 96,88 & 89,77 & 98,29 \\
\hline b. Mayangan & - & 97,35 & 90,94 & 98,33 \\
\hline
\end{tabular}

Sumber : Data Primer, 2013

Tabel 3 menunjukkan hasil uji kualitas effluent air limbah rata-rata di Kelurahan Pilang dan Mayangan untuk semua parameter masih di bawah baku mutu lingkungan sesuai dengan Keputusan Menteri Lingkungan Hidup Nomor 1122003 tentang Baku Mutu Limbah Domestik. Hal ini menunjukkan bahwa teknologi yang digunakan cukup handal dalam menurunkan beban pencemar limbah domestik yang ada.

Tingkat kehandalan pada masing-masing IPAL juga dapat dilihat dari \%tase penurunan parameter effluent air limbah dibandingkan dengan Influent air limbah. Konsentrasi air limbah pada influent IPAL mengacu pada karakteristik limbah domestik dan limbah perkotaan rata-rata yaitu parameter BOD sebesar 353,43 mg/lt, TSS sebesar 119,25 mg/lt, minyak dan lemak sebesar $63 \mathrm{mg} / \mathrm{lt}$ (Said, 2000). Berdasarkan tabel 3 terlihat bahwa kehandalan IPAL komunal di kedua lokasi cukup tinggi dengan penurunan konsentrasi seluruh parameter air limbah lebih dari 89 \%. Hal ini memperkuat pernyataan Abdullah et al. (2005) yang menyatakan bahwa salah satu kelebihan dari teknologi ABR adalah memiliki tingkat efisiensi pengolahan yang tinggi.

\subsection{Status Keberlanjutan Si stem Berdasarkan hasil perhitungan} atau skoring terhadap indikatorindikator pada masing-masing variabel, diperoleh status keberlanjutan sistem pengelolaan air limbah domestic komunal sebagaimana tabel 4 di bawah ini :

Tabel 4.Status Keberlanjutan Sistem Pengelolaan Air Limbah

\begin{tabular}{|c|c|c|c|}
\hline Variabel Keberlanjutan & Pilang & Mayangan & Kota \\
\hline Aspek Teknis & 2,76 & 2,06 & 2,41 \\
\hline Aspek Pembiayaan & 1,96 & 1,82 & 1,89 \\
\hline Aspek Kelembagaan & 2,15 & 2,32 & 2,24 \\
\hline $\begin{array}{l}\text { Aspek Peranserta } \\
\text { Masyarakat }\end{array}$ & 1,97 & 1,99 & 1,98 \\
\hline Aspek Kualitas Lingkungan & 3,00 & 3,00 & 3,00 \\
\hline Jumlah & 11,76 & 11,19 & 11,52 \\
\hline Rata-rata & 2,35 & 2,24 & 2,30 \\
\hline Status & Tinggi & Sedang & Sedang \\
\hline
\end{tabular}

Sumber : Data Primer, 2013

Tabel 4 di atas menunjukkan bahwa status keberlanjutan sistem pengelolaan air limbah komunal di di Kota Probolinggo masuk dalam 
kategori sedang (1,67-2,33). Kehandalan teknologi yang digunakan memberikan kontribusi yang besar dalam keberlanjutan sistem. Namun demikian, kepadatan penduduk di Kelurahan Mayangan menjadi kendala tersendiri terutama dalam hal kebutuhan lahan untuk pengembangan sistem pengolahan IPAL dengan teknologi yang sama.

Aspek pembiayaan memberikan memiliki skor keberlanjutan yang sedang, karena memang dominasi pemerintah dalam investasi pembangunan sangan tinggi dibandingkan peran masyarakat. Namun, dalam pembiayaan untuk operasional dan pemeliharaan, masyarakat memiliki kemampuan dan kemauan dalam membiayainya. Peran serta masyarakat di kedua kelurahan tersebut juga masih masuk dalam kategori sedang.

Beberapa hal yang mempengaruhi kurangnya keterlibatan masyarakat antara lain pemahaman masyarakat terhadap fungsi pegelolaan air limbah dan pentingnya pemeliharaan sistem masih rendah serta pembagian peran antara lembaga pengelola yang ada dan masyarakat sebagai pemanfaat belum jelas. Kelembagaan pengelola air limbah ditingkat lokal yang telah terbentuk maupun ditingkat pemerintah belum bekerja secara optimal terutama dalam kegiatan pemeliharaan sistem dan peningkatan sumber daya manusia.

\subsection{Strategi Keberlanjutan Sistem}

Berdasarkan hasil analisis SWOT, dapat diketahui posisi kuadran strategis berada di posisi kuadran II. Posisi tersebut menunjukkan bahwa sistem pengelolaan air limbah domestik komunal di Kota Probolinggo masih memiliki banyak kelemahan, namun di sisi lain juga memiliki banyak peluang untuk dimanfaatkan. Untuk itu, strategi yang diperlukan untuk meningkatkan keberlanjutan sistem adalah strategi stabilitas atau konsolidasi dimana strategi ini berujuan untuk mengurangi kelemahan-kelemahan yang ada melalui pemanfaatan peluang yang dimiliki.
Strategi yang diperlukan untuk meningkatkan keberlanjutan sistem pengelolaan air limbah domestik Kota Probolinggo adalah strategi O-W (stabilitas), antara lain :

1. Pengembangan kapasitas masyarakat dan kelembagaan pengelola air limbah

2. Pengembangan alternatif pembiayaan pengelolaan air limbah berbasis kemitraan

3. Peningkatan koordinasi dan pembagian peran pada POKJA sanitasi dalam mendukung pengelolaan air limbah di tingkat lokal

\section{KESIMPULAN DAN SARAN}

\subsection{Kesimpulan}

Status keberlanjutan sistem pengelolaan air limbah di Kota Probolinggo masuk dalam kategori Sedang dengan total skor 2,30. Kondisi ini didukung oleh pemilihan teknologi yang tepat baik dari sisi kehandalan maupun kemudahan pengoperasian dan pemeliharaannya, sehingga menghasilkan penurunan beban pencemaran yang tinggi. Pengelolaan air limbah domestik komunal dilaksanakan oleh kelembagaan di tingkat lokal yang berbentuk Kelompok Swadaya Masyarakat (KSM), namun dalam pelaksanaannya belum sepenuhnya optimal. Telah memiliki mekanisme pembiayaan untuk operasional dan pemeliharaan, keterlibatan masyarakat dalam pembangunan dilakukan melalui kontribusi dalam bentuk incash dan inkind, sedangkan keterlibatan masyarakat dalam tahap operasional yang nampak adalah kesediaan membayar iuran rutin sebesar Rp. 1000/bulan untuk Kelurahan Pilang dan Rp. 3000/bulan untuk Kelurahan Mayangan.

Strategi yang diperlukan dalam upaya meningkatkan keberlanjutan sistem pengelolaan air limbah domestik komunal di Kota Probolinggo adalah pengembangan kapasitas masyarakat dan kelembagaan pengelola air limbah, pengembangan alternatif pembiayaan pengelolaan air limbah berbasis kemitraan dan peningkatan koordinasi, serta pembagian peran pada POKJA 
sanitasi dalam mendukung pengelolaan air limbah di tingkat lokal.

\subsection{Saran}

Pembangunan sarana pengolahan air limbah komunal dengan konsep pengelolaan berbasis masyarakat memerlukan kesiapan sumber daya manusia di tingkat lokal. Untuk itu, upaya peningkatan kapasitas sumber daya manusia tidak cukup hanya dilakukan pada tahap perencanaan dan berhenti pada tahap pembangunan, diperlukan upaya pembinaan dan monitoring oleh pemerintah pada pasca tahap pembangunan untuk meningkatkan kapasitas kelembagaan dan masyarakat sehingga keberlanjutan sistem pengelolaan air limbah dapat terjaga.

\section{REFERENSI}

Abdullah, A.G.L., A.Idris, F.R.Ahmadun, B.S.Baharin, F.Emby, M.J.Megat Mohd Noor, A.H. Nour, 2005. A kinetic study of a membrane anaerobic reactor (MAR) for treatment of sewage sludge. Desalination 183: 439-445

Balkema, J. A., H. A.Preisig, R. Otterpohl, F. J. D. Lambert, 2002. Indicator for The Sustainability Assesment of Wastewater Treatment Systems. Urban Water. $4: 153-161$

Bappeda, 2010.Strategi Sanitasi Kota Probolinggo.

Bappenas, 2008. Proyeksi Penduduk Indonesia 2005-2025. BPS, Bappenas dan UNFPA Indonesia. ISBN: 978-979724-939-7

Bappenas, 2012. Laporan Pencapaian Tujuan Milenium Indonesia Tahun 2011

BPS, 2012.Kota Probolinggo dalam Angka

Fatnasari, H. dan J.Hermana, 2010. Strategi Pengelolaan Air Limbah Permukiman Di Bantaran Kali Surabaya. Prosiding Seminar nasional Manajemen Teknologi XI. MMT-ITS. Surabaya
Hindarko, 2003. Mengolah Air Limbah Supaya Tidak Mencemari Orang Lain. Penerbit Esha. Jakarta

Kurniawan, A., 2012. Konsep Desain Instalasi Pengolahan Air Limbah Skala Komunal Dalam Rangka Purifikasi Kualitas Air Sungai Di Jakarta. Proseeding Annual Engineering Seminar 2012. Universitas Gajah Mada

Kustiah, T., 2005.Kajian Kebijakan Pengelolaan Sanitasi Berbasis Masyarakat.Kolokium. Puslitbang Departemen PU

Masduki, A., N. Endah, E. S. Sudjono, 2008. Sistem Penyediaan Air Bersih Perdesaan Berbasis Masyarakat: Studi Kasus HIPPAM di DAS Brantas Bagian Hilir. Prosiding Seminar Nasional Pascasarjana VIIIITS, Surabaya.

Massoud,M.A.J.Tareen, J.Nasr, M.Jurdi, 2010. Effectiveness of wastewater management in rural areas of developing countries: a case of AlChouf Caza in Lebanon. Environ Monit Assess: 161:61-69

Parkinson, J. and K.Tayler, 2003. Decentralized Wastewater Management in Peri-urban areas in Low-income Countries. Environmental and Urbanization Vol 15. No. 1

Prihandrijanti,M. dan M.Firdayati, 2011.Current Situation ang Consideration of Domestic Wastewater Treatment System for Big Cities in Indonesia (Case Study : Surabaya and Bandung). Journal of Water Sustainability, Vol 1, Issue 2: 97-104

Said, N. I., 2000.Pengelolaan Air Limbah Domestik di DKI Jakarta. Pusat Teknologi Lingkungan BPPT. Jakarta

Soedjono S., A. Masduki, A. Purnomo, A. T. Rumiati, M. Starki, 2010. Pilihan Teknologi untuk Pengolahan Air limbah Domestik di Daerah Peri Urban dan Pedesaan di Jawa Timur. Jurnal Purifikasi. Vol. 11, No. 2 : 177 184 